\title{
Effect of Aloe vera Gel and Gum arabic Coating on Shelf Life and Nutrient Content of Green Capsicum (Capsicum annuum L)
}

\author{
M. Amirthaveni ${ }^{1}$ and Palak Daga ${ }^{2 *}$ \\ 'Professor and Head of Food Science and Nutrition, Avinashilingam University for Women, \\ Coimbatore, Tamil Nadu, India; amrithaveni@gmail.com \\ ${ }^{2} \mathrm{PG}$ Student, Avinashilingam University for Women, \\ Coimbatore, Tamil Nadu, India
}

\begin{abstract}
Capsicum, a common name of Capsicum annuum L., is an annual herbaeceous plant of the Capsicum genus belonging to the Solanaceae family. India contributes to one fourth of the world production of capsicum with an average annual production of 0.9 million tons. About 1.67 million metric tonnes of capsicums was produced in India during the period of 20132014. Capsicums are highly perishable and harvested over a restricted period. Therefore the need for proper storage techniques arises to regulate marketing and to provide high-quality produce throughout the year. Edible coatings are thin layer of edible materials formed directly onto the surface of the food that can be eaten as part of the whole product without bringing any undesirable change in the foodstuff. Use of edible coatings as an alternative post harvest preservation technique for fruits and vegetables has been gaining an increasing interest. Green capsicum was coated with two different coatings made of gum Arabic and Aloe vera gel and were kept at refrigerated and ambient storage for a period of 25 days and were observed for the post harvest quality characteristics. It was seen that these edible coatings were found to be effective and acceptable in extending the shelf life of capsicum in both refrigerated as well as ambient conditions. However, the capsicums stored in refrigerator were found to be marketable for a long period of time. The edible coatings showed remarkable retention of nutrients during storage.
\end{abstract}

Keywords: Aloe Vera Gel, Ambient Conditions, Capsicum, Edible Coatings, Gum Arabic

\section{Introduction}

Green capsicum (Capsicum annum L.) is a non climacteric fruit that is produced in many parts of the world for culinary and vegetable uses ${ }^{1}$. According to data given by FAO, capsicums are highly perishable and harvested over a restricted period, therefore the need for proper storage facilities arises to regulate marketing and to provide high-quality produce throughout the year. According to Food Waste Campaign, fruits and vegetables contribute to about 45 per cent of the food losses, which accounts to almost half of what is produced ${ }^{2}$. So determining the best technique to preserve the post harvest quality of fruits and vegetables is of prime importance ${ }^{3}$ as the purchase decision of the handlers and consumers depends on the quality characteristics like retention of fruit green colour, freshness, firmness as well as absence of defects and disease $^{4}$.

\section{Materials and Methods}

Matured green capsicums were collected from the wholesale vegetable market in Coimbatore. Aloe vera was procured from RGM Aloe vera Products, Vellalore, Coimbatore, while, Gum Arabic was obtained from New Market, Kolkata.

Capsicums with bruises, signs of infection or those different from the group were discarded from the samples. Uniform, unblemished fruits of similar size and green skin colour were then selected and hand washed

${ }^{*}$ Author for correspondence 
with tap water to remove soil particles and to reduce microbial population on the surface. Then the capsicums were surface dried with soft cloth ${ }^{1,5}$. A total of 120 capsicums were used for the study.

\subsection{Preparation of Coating Solution}

\subsubsection{Aloe Vera Gel Solution (AV)}

Mature green leaves of Aloe vera plant was procured and washed with tap water to remove dirt and soil particles. The skin of the leaves was peeled and gel matrix was then separated from the outer cortex of the leaves to obtain the colourless hydro parenchyma. Aloe vera gel solution with a concentration of 30 per cent $(w / v)$ was used as a base coating. It was prepared by blending 30 grams of the obtained gel in a food blender. The solution obtained was then filtered using muslin cloth to remove the fibres. The liquid obtained constituted of fresh Aloe vera gel which was further dissolved in $100 \mathrm{ml}$ of distilled water to get the desired concentration of solution ${ }^{6,7}$.

\subsubsection{Gum Arabic Solution (GA)}

Gum Arabic with a concentration of 10 per cent (w/v) was prepared by dissolving 10 grams of Gum arabic in $100 \mathrm{ml}$ of distilled water. The solution was then stirred on a magnetic stirrer/hot plate (Neolab Motorless Magnetic Stirrer + Hot Plate) at low temperature but high speed for 60 minutes. The prepared solution was then cooled and filtered through muslin cloth to remove any undissolved impurities.

\subsection{Coating of Capsicum}

The capsicums were randomly divided into three sets. Each set contained 40 capsicums. Capsicum in each set was given different treatments which are as follows:-

- Control (CC)

- Aloe vera Gel Solution (AV)

- Gum Arabic Solution (GA)

Each set was immersed in their respective coating solution for one minute. Capsicums dipped in distilled water were taken as control. Treated capsicums were kept over a metal sieve for 1 hour and a fan generating low speed air was used to accelerate drying and to remove surface moisture. Visual appearance of a dry layer with plastic texture was used as a criterion to determine the end of drying process?.

\subsection{Storage of Coated Capsicum}

After drying, each set was divided into two sub sets, each containing 20 capsicums, where one subset was stored at ambient conditions (A) having a temperature range between $30-32^{\circ} \mathrm{C}$ and $65-67 \%$ relative humidity, while the other subset was stored in refrigerator and were coded as (R). Among the two subsets, 10 capsicums labelled $\mathrm{P}$ were used for determination of Post Harvest quality characteristics, while the other 10 capsicums labelled $\mathrm{N}$ were used for nutrient analysis

In order to create a strong texture $2 \%$ calcium chloride was added to all the above coating $5^{5,10}$.

As an additional precautionary measure, the sorted capsicums were dipped in $0.05 \%$ sodium hypochlorite solution prior to dipping in coating solution, which acted as a disinfectant. After dipping, the capsicum were rinsed with de ionized water and air dried at ambient temperature.

\subsection{Post Harvest Quality Characteristics and Nutritive Value}

For post-harvest quality characteristics and nutrient analysis, the capsicums were analyzed after a regular interval of 5 days $\left(0^{\text {th }}, 5^{\text {th }}, 10^{\text {th }}, 15^{\text {th }}, 20^{\text {th }}, 25^{\text {th }}\right)$ till the period they were acceptable for marketing ${ }^{11}$.

\subsubsection{Determination of Post-Harvest Quality Characteristics}

At $0^{\text {th }}$ day and at the end of each storage interval, capsicums labeled A from each subset of both storage conditions were analyzed for post harvest quality characteristics.

\subsubsection{Percentage of Weight Loss}

Set $\mathrm{P}$ of each treatment, namely CCA, AVA, GAA, CCR, AVR and GAR were weighed at the $0^{\text {th }}$ day and at the end of each storage interval. The difference between the initial weight and final weight of fruit was considered as total weight loss which was expressed as percentage on a fresh weight basis as per standard method of AOAC, $1994^{12}$.

Percentage weight loss $(\%)=[(\mathrm{I}-\mathrm{F}) / \mathrm{I}] \mathrm{x} 100$

Where I indicate the initial fruit weight and F indicated the fruit weight after storage intervals. 


\subsubsection{Percentage of Decay}

The decay percentage of both coated and control capsicums were calculated as the number of decayed fruits divided by initial number of all fruits multiplied by $100^{13}$.

\subsubsection{Sharpness of Cut Surface}

The sharpness of cut surface was observed after cutting the capsicums with a stainless steel knife at the end of each storage interval ${ }^{1}$.

\subsubsection{Marketable Quality of Capsicum}

During each day of the study period, the marketability of the fruits was assessed using a nine point rating scale. The colour, firmness, surface defects, signs of mould growth and shrivelling were used as visual parameters for the rating. Fruits that received a rating of five and above were considered marketable, while those rated less than five were considered unmarketable ${ }^{1}$.

\subsubsection{Nutrient Analysis}

At $0^{\text {th }}$ day and at the end of each storage interval, 1 capsicum labelled $\mathrm{N}$ from each subset was analyzed for proximate composition and ascorbic acid using standard techniques of National Institute of Nutrition, Hyderabad ${ }^{14}$.

\section{Results and Discussion}

\subsection{Post- Harvest Quality Characteristics}

Postharvest quality is a combination of characteristics or attributes, which gives value to the commodity in terms of its intended use. The capsicums stored in ambient conditions started deteriorating after the $15^{\text {th }}$ day whereas those stored in refrigeration were in better condition. So the data for capsicums stored in ambient conditions were recorded till $15^{\text {th }}$ day, while for capsicums stored in refrigeration the data was collected till $25^{\text {th }}$ day. Values given in Tables 1 to 5 are the mean \pm SD of three samples in each group. Values with different superscript letters in the same row for each treatment are significantly different at the 0.05 level $(\mathrm{p}<0.05)$

\subsubsection{Percentage of Weight Loss}

Table 1 shows the weight loss percentage of capsicum during storage. The percentage of weight loss in control samples was found to be significantly $(\mathrm{p}<0.05)$ higher than that of coated samples. During the storage period,

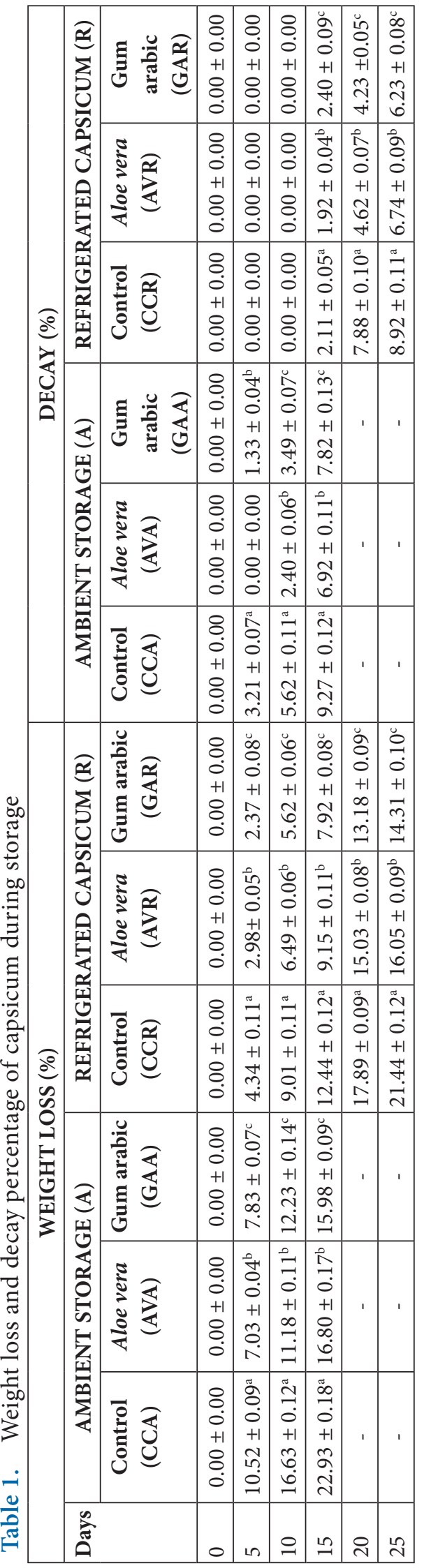

FoodSci:Indian Journal of Research in Food Science and Nutrition 
coatings were found to significantly $(\mathrm{p}<0.05)$ reduce the decay percentage when compared to the control samples. Capsicums stored at refrigerated condition showed no loss in sharpness of cut surface till $15^{\text {th }}$ day of storage. On $20^{\text {th }}$ day of storage slight loss in sharpness was seen for CCR, while at the end of the study period loss in sharpness of cut surface was seen both for coated and uncoated capsicums. During the entire length of experiment the percentage of weight loss in control samples was found to be significantly $(\mathrm{p}<0.05)$ higher than that of coated samples.

\subsubsection{Decay Percentage}

Table 1 shows the Decay percentage of capsicum during storage. At the end of $25^{\text {th }}$ day, decay percentage was found to be highest in control samples.

\subsubsection{Marketable Quality and Moisture Content}

Table 2 shows the marketable quality and moisture content of capsicum during storage. A significant reduction $(\mathrm{p}<0.05)$ in percentage marketability of uncoated capsicums was seen when compared to coated ones during both storage conditions. The coatings showed a significant $(p<0.05)$ decrease in the moisture content when compared with the control samples. Among the coatings there existed a significant difference in ambient conditions, but in refrigerated conditions no significant difference was seen among the coatings.

\subsubsection{Nutrient Content of Capsicum during Storage}

Table 3, 4 and 5 show the nutrient content of the capsicums during storage. The protein content of uncoated samples was significantly $(\mathrm{p}<0.05)$ lower than that of coated samples, at both ambient and refrigerated storage conditions. However among the coatings no significant difference in the protein content was observed. The fat content of uncoated samples was significantly $(p<0.05)$ lower than coated samples at both ambient and refrigerated storage conditions. Among the coatings there was no significant difference in ambient condition, whereas at refrigerated condition, GAR showed significantly different fat content. The control capsicums showed significantly $(p<0.05)$ lower retention of calcium content when compared with coated samples at both ambient and refrigerated storage conditions. At the end of $15^{\text {th }}$ day for capsicums stored at ambient condition, there was significant $(\mathrm{p}<0.05)$ decrease in the phosphorus content of CCA and AVA, whereas GAA and AGA showed significantly

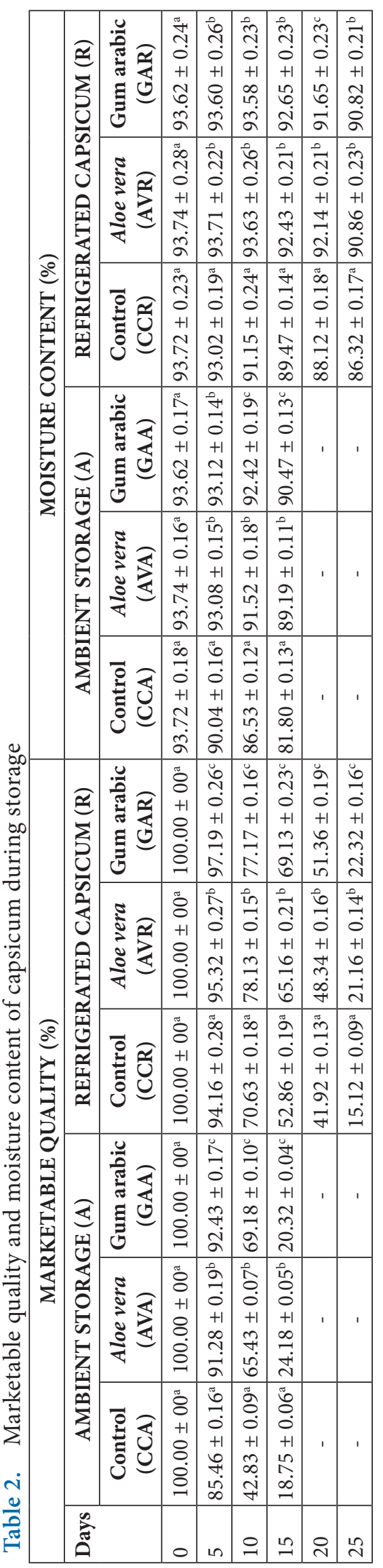

FoodSci:Indian Journal of Research in Food Science and Nutrition 


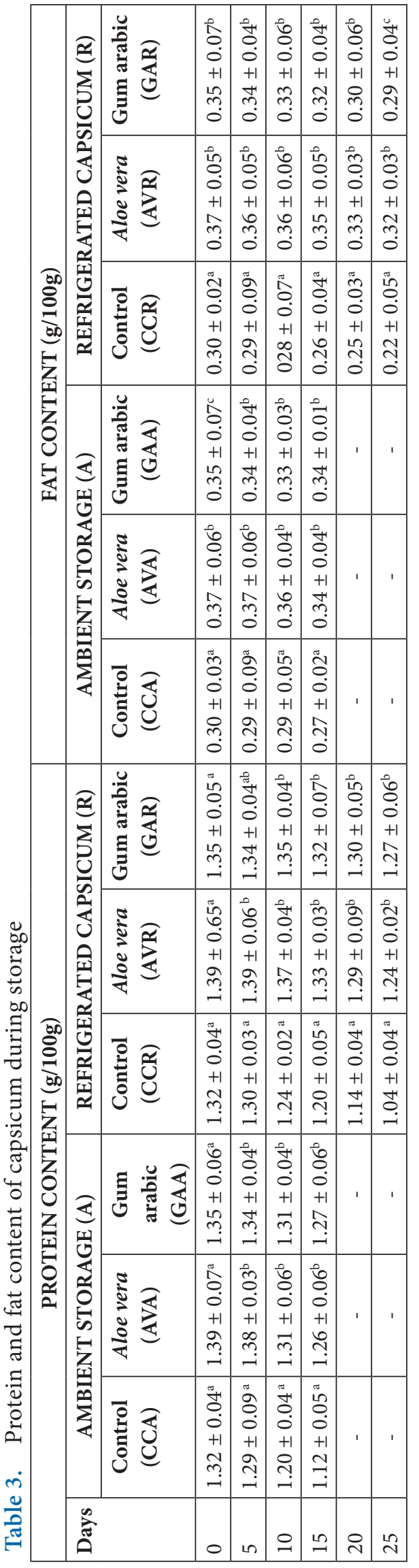

Vol 3 (2), July-December 2016

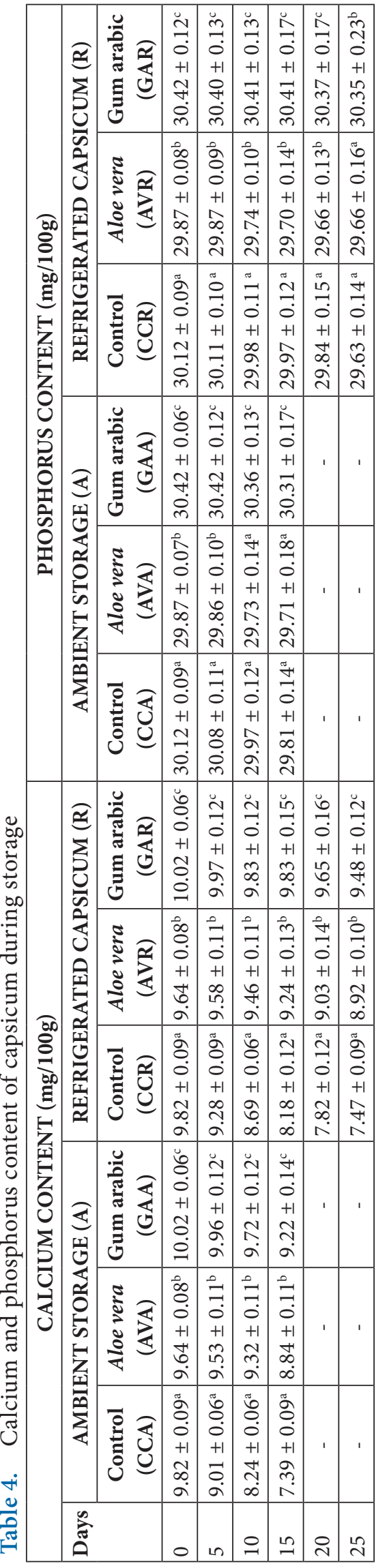

FoodSci:Indian Journal of Research in Food Science and Nutrition $\mid$ 4I 


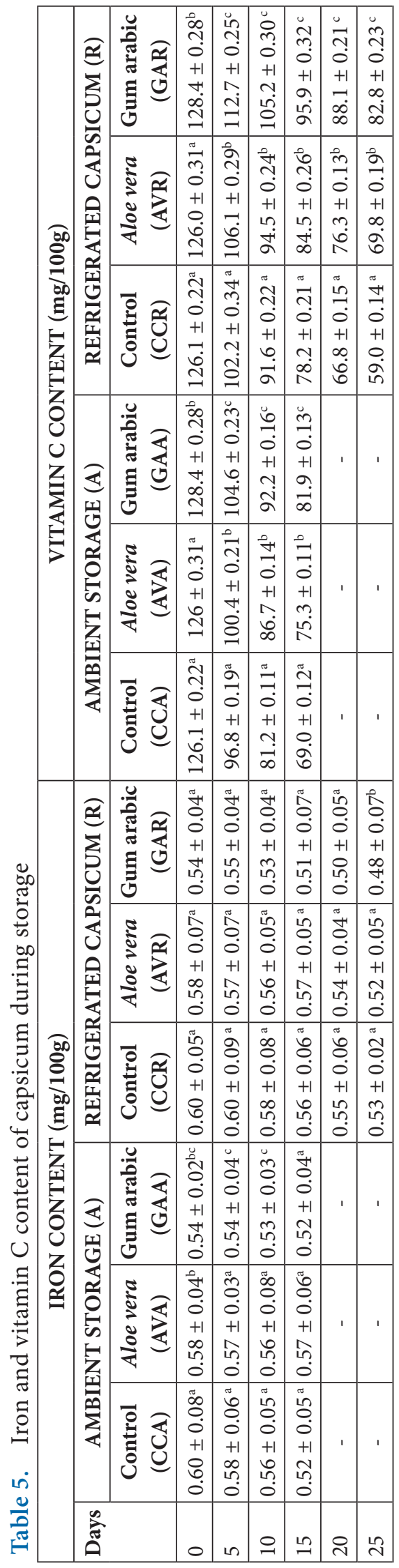

higher retention of phosphorus (30.31 mg and $30.48 \mathrm{mg}$ respectively), when compared to CCA $(29.81 \mathrm{mg})$. At $25^{\text {th }}$ day of refrigerated storage, maximum loss of phosphorus was seen in case of CCR $(29.63 \mathrm{mg})$ and AVR $(29.66 \mathrm{mg})$. GAR showed significantly higher retention of phosphorus, having $30.35 \mathrm{mg}$ and $30.54 \mathrm{mg}$ respectively. At ambient storage at the end of $15^{\text {th }}$ day, the capsicum of all treatments showed no significant $(\mathrm{p}<0.05)$ difference in iron content amongst each other. The decrease in Vitamin C was found to be gradually increasing during the storage period and the decrease was significantly $(\mathrm{p}<0.05)$ more in control samples when compared to coated capsicums at both storage conditions.

\section{Conclusion}

The present study was aimed at extending the shelf life of capsicum, as it is a nutrient rich vegetable. But being perishable in nature large amount of nutrient and organoleptic quality loss is seen. Further, the aim was to study the efficacy of Aloe Vera gel and Gum Arabic coatings on capsicum and to analyse the effect of these coatings on nutrient content of the capsicum during storage. From the study, it may be concluded that Aloe Vera gel and Gum Arabic holds potential for the development of edible coating. These edible coatings were found to be effective and acceptable in extending the shelf life of capsicum in both refrigerated as well as ambient conditions. However, the capsicums stored in refrigerator were found to be marketable for a long period of time. The edible coatings showed remarkable retention of nutrients during storage. The quality characteristics of the coated capsicum were noted to be better compared to the uncoated samples. The studied coatings being economical and bio degradable, emerges as a promising alternative in reduction of post harvest losses and thereby enhancing food security.

\section{References}

1. Samira A, Woldesadik K, Workneh ST. Postharvest quality and shelf life of some hot pepper varieties. Journal of Food Science and Technology. 2013; 50:842-55.

2. Basiya RK. Developed countries contribute more to global food wastage. Processed Food Industry. 2014; 17:8-10.

3. Cresopo CP, Amor FM. Effects of postharvest treatments on fruit quality of sweet pepper at low temperature. Journal of Food Science and Agriculture. 2010; 90:2716-72. 
4. Nyanjage MO, Nyalala SPO, Illa AO, Mugo BW, Limbe AE, Vulimu EM. Extending post-harvest life of sweet pepper (Capsicum annum L. 'California Wonder') with modified atmosphere packaging and storage temperature. Agricultura Tropica Et Subtropica. 2005; 38:28-32.

5. Mohebbi M, Hasnpour N, Ansarifar E, Amiryousefi MR. Physicochemical properties of bell pepper and kinetics of its colour change influenced by aloe vera and gum tragacanth coatings during storage at different temperatures. Journal of Food Processing and Preservation. 2014; 38:684-93.

6. Marpudi SL, Abirami LSS, Pushkala R, Srividya N. Enhancement of storage life and quality maintenance of papaya fruits using Aloe vera based antimicrobial coating. Indian Journal of Biotechnology. 2011; 10:83-9.

7. Yulianingsih R, Maharani DM, Hawa LC, Sholikhah L. Physical quality observation of edible coating made from aloe vera on cantaloupe (Cucumismelo L.) minimally processed. Pakistan Journal of Nutrition. 2013; 12:800-5.

8. Hedayati S. Niakousari M. Effect of silver nanoparticles and gum Arabic coatings on physicochemical and microbial properties of green bell pepper (Capsicum annum). Journal of Food Processing and Preservation. 2015.
9. Juhaimi FA, Ghafoor K, Babiker E. Effect of gum Arabic coating on weight loss, firmness and sensory characteristics of cucumber (Cucumis Sativus L.) fruit during storage. Pakistan Journal of Biology. 2012; 44:1439-44.

10. Chauhan S, Gupta KC, Agarwal M. A new approach of hurdle technology to preserve mango fruit with the application of aloe vera gel and calcium chloride. International Journal of Current Microbiology and Applied Science. 2014; 3:92634.

11. Srinivasa PC, Prashanth KVP, Susheelamma NS, Ravi R, Tharanathan RN. Storage studies of tomato and bell pepper using eco-friendly films. Journal of Food Science and Agriculture. 2006; 86:1216-24.

12. Leon JL, Elias JL, Lopez MAH, Lopez AMG, Orti SR, Gracia LFE. Postharvest quality and shelf life of green pepper (Capsicum annum L.) grown under open-field and greenhouse conditions. IDESIA. 2013; 31:35-41.

13. Gol NB, Chaudhari ML, Rao TVR. Effect of edible coatings on quality and shelf life of carambola L fruit during storage. Journal of food science and technology. 2013.

14. Rahuramulu N, Nair KM, Kalyanasundaram S. A Manual of laboratory techniques. Hyderabad: National Institute of Nutrition; 2003. 